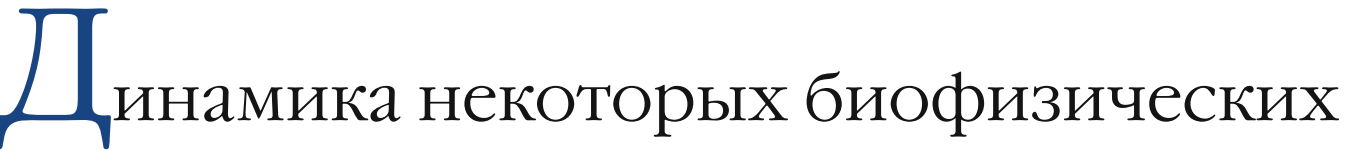 параметров кожи человека в процессе оптического просветления при воздействии гиперосмотических агентов
}

\author{
С.Р. Утцํㅜ, В.В. Тучин ${ }^{2}$, Е.М. Галкина ${ }^{1}$
}

${ }^{1}$ ГБОУ ВПО «Саратовский государственный медицинский университет им. В.И. Разумовского» Минздрава России

410012, г. Саратов, ул. Б. Казачья, 112

${ }^{2}$ Национальный исследовательский Саратовский государственный университет им. Н.Г. Чернышевского 410012, г. Саратов, ул. Астраханская, 83

\footnotetext{
Цель работы. Изучить динамику некоторых биофизических параметров кожи человека в процессе оптического (иммерсионного) просветления при воздействии гиперосмотических агентов.

Материал и методы. Измерения проводились на коже (на правой и левой руке) 18 добровольцев женского пола, возраст которых составлял от 17 до 38 лет. Определение биосизических параметров кожи и ее фрототипа проводилось с помощью аппарата для диагностики состояния кожи Soft Plus (Callegari, Италия) эритемамеланинометра (ЭММ-002E, Россия). В качестве исследуемых гиперосмотических (дегидратирующих) агентов использовались водные растворы глюкозы с концентрацией 30, 40 и 50\%, а также 50\% водно-спиртовой (30) раствор фрруктозы.

Результаты. Показано, что степень и время дегидратации кожи существенно определяются способом аппликации иммерсионного агента и его составом. В зависимости от применяемой технологии можно получить как уменьшение, так и увеличение степени увлажнения кожи, что связано с фризиологическим ответом кожи на окклюзию и осмотическое действие препаратов. Наиболее эффективным дегидратирующим агентом из исследованных является 50\% водно-спиртовой раствор фрруктозы.
}

Ключевые слова: биофизические параметры кожи, дегитратирующие агенты, оптическое просветление.

Контактная информация: s_utz@mail.ru. Вестник дерматологии и венерологии 2015; (4): 60—68. 


\title{
The dynamics of some human skin biophysical parameters in the process of optical clearing after hyperosmotic solutions topical application
}

\author{
S.R. Utz ${ }^{1}$, V.V. Tuchin², E.M. Galkina ${ }^{1}$
}

${ }^{1}$ Saratov State Medical University named after V.I. Rasumosky

B. Kazachya str., 112, Saratov, 410012, Russia

${ }^{2}$ Saratov State University named after N.G. Chernyshevsky

Astrakhanskaya str., 83, Saratov, 410012, Russia

Goal of the study. To study changes of certain biophysical parameters of human skin in the process of optical (immersion) clarification under the effect of hyperosmotic agents.

Materials and methods. Measurements were made on the skin (on the right and left hands) of 18 female volunteers aged

17-38. Biophysical parameters of the skin and its phototype were determined with the use of Soft Plus, a device for the diagnostics of the skin condition (Callegari, Italy), and erythema melanin meter (EMM-002E, Russia). 30\%, 40\% and $50 \%$ aqueous glucose solutions as well as $50 \%$ aqueous-alcoholic $\left(30^{\circ}\right)$ fructose solution were used as hyperosmotic (dehydrating) study agents.

Results. It was revealed that the extent and time of skin dehydration mostly depend on the method of application of the immersion agent and its composition. Depending on the applied technology, it is possible to achieve both a decrease and an increase in the skin moisture extent, which is related to the physiological response of the skin to the occlusion and osmotic action of the agents. 50\% aqueous-alcoholic fructose solution appears to be the most efficient dehydrating agent of all study agents.

Key words: biophysical skin parameters, dehydrating agents, optical clarification. 
Оптические методы диагностики занимают приоритетное место в арсенале врача-дерматовенеролога [1-3]. Они уникальны по информативности, достаточно просты в применении, неинвазивны, а соответственно, безопасны и относительно дешевы в сравнении, например, с компьютерной и магнитно-резонансной томографией. Основным ограничением для совершенствования диагностических процедур, использующих обычные или лазерные источники света (оптической когерентной спектроскопии, конфокальной микроскопии, спектроскопии отражения и аутофрлюоресценции и др.), является сильное светорассеяние в биологических тканях и жидкостях, что значительно снижает пространственное разрешение этих методов, ограничивает глубину зондирования и контраст получаемого изображения [4].

Высокие показатели коэфффициента рассеяния $\left(\mu_{\mathrm{s}}\right)$ и фрактора анизотропии $(\mathrm{g})$ для эпидермиса обусловлены существенными различиями в светопреломлении между компонентами клеточных элементов (плазматической мембраной клеток и митохондрий, ядер и других внутриклеточных органелл, а также цитоплазмы и внеклеточной жидкости) и клеточных слоев. В дерме значительное рассеяние света вызвано различием коэффициентов преломления света между межклеточной жидкостью и цитоплазмой и многочисленными цепочками склеропротеинов (коллагена, эластина и ретикулина) [5].

Для увеличения глубины зондирования кожи оптическим излучением были разработаны многочисленные способы и приемы [6]. Одним из достаточно простых и эфффективных способов увеличения глубины зондирования и повышения качества изображения является временное снижение светорассеяния, так называемое оптическое просветление кожи (ОПК) [79]. Интерес к ОПК постоянно растет, что обусловлено прогрессом оптических и лазерных технологий в дерматологии и косметологии.

Методики ОПК основаны на сжатии [10], растяжении [11], обезвоживании [12], коагуляции кожи [13], а также нанесении на ее поверхность или введении внутрь ее слоев биосовместимых иммерсионных жидкостей [14]. Предложены также методы фротохимического [15] и фрототермического [16] просветления.

Большинство методик, снижающих светорассеяние кожи, базируются на согласовании показателей преломления ее компонентов либо на замене межтканевой жидкости иммерсионным агентом, обладающим более высоким показателем преломления. Оптическая однородность кожи может увеличиться также за счет уплотнения рассеивающих центров, что связано с «выдавливанием» тканевой жидкости из исследуемого объема и обезвоживанием за счет воздействия агента или испарения воды [14]. Кожа человека, как и большинство других биологических тканей, сильно рассеивает зондирующий свет в видимом и ближнем инфракрасном (ИК) диапазонах [5]. В терагерцовом диапазоне длин волн (частота $10^{11}-10^{13}$ Гц, диапазон длин волн 3-0,03 мм) рассеяние излучения на неоднородностях биотканей незначительно. Проницаемость излучения в ткань определяется не рассеянием, а поглощением воды. Коэфффициент поглощения может достигать нескольких сотен обратных сантиметров [4]. Поскольку большинство оптических просветляющих агентов обладают дегидратирующим свойством [17], представляется возможным временно снизить содержание воды в ткани и тем самым уменьшить ее коэффрициент поглощения или соответственно увеличить глубину зондирования терагерцового излучения, что важно для диагностики, например, предраковых состояний кожи.

В настоящей работе представлены результаты изучения динамики некоторых биофизических параметров кожи человека в процессе иммерсионного просветления при воздействии гиперосмотических агентов.

\section{Материал и методы}

Исследования биофизических параметров кожи проводились на участке внутренней поверхности предплечья. Эта область была выбрана из соображений меньшей толщины рогового слоя и более низкой подверженности загару (меланиновой пигментации). Измерения проводились на коже (на правой и левой руке) 18 добровольцев женского пола, возраст которых составлял от 17 до 38 лет (средний возраст $26,2 \pm 5,6$ года). Среди добровольцев были 3 человека со вторым фототипом кожи, 11 - с третьим фрототипом и 4 - с четвертым фототипом.

Определение биофизических параметров кожи и ее фототипа проводилось с помощью аппарата для диагностики кожи Soft Plus (Callegari, Италия). С его помощью оценивали два параметра - увлажнение и температуру кожи в зависимости от времени воздействия иммерсионного агента. Измерение увлажнения рогового слоя на аппарате Soft Plus осуществляется с помощью емкостного метода $[18,19]$.

Кожа участвует в терморегуляции температуры тела человека за счет изменения количества крови, протекающей через сосуды дермы, а также за счет испарения пота. Кровеносные капилляры кожи и потовые железы находятся под автономным контролем. Измерение температуры кожи на аппарате Soft Plus осуществлялось с помощью бесконтактного ИKдатчика, способного измерять температуру в диапазоне $20-40{ }^{\circ} \mathrm{C}$ с точностью $0,1^{\circ} \mathrm{C}$. Такая точность обеспечивается оптической системой наведения датчика на поверхность, которая определяет оптимальное расстояние до измеряемого объекта, для которого и производится измерение температуры исследуемого участка при регистрации ИК-излучения, поступающего от исследуемого объекта. 
В качестве измеряемого параметра был также выбран индекс эритемы (ИЭ), который характеризует изменение объема крови в поверхностных и глубоких кровеносных сплетениях дермы и должен косвенно отражать кинетику жидкостей в коже при воздействии гиперосмотических агентов. ИЭ определялся с помощью светодиодного эритема-меланинометра (ЭММ-002Е, Россия, регистрационное удостоверение № ФС 02а2005/285-06). Показатели степени эритемы для видимо неизмененнной кожи лежат в диапазоне 100-130 ед. (среднее значение $115 \pm$ 5,8 ед.). Принцип действия прибора основан на измерении параметров оптического отражения кожи в желто-зеленой и красной областях спектра [20] и определяется как величина, пропорциональная площади под кривой спектральной зависимости оптической плотности кожи в желто-зеленой области спектра.

В качестве исследуемых гиперосмотических (дегидратирующих) агентов использовались водные растворы глюкозы с концентрацией 30, 40 и 50\%, а также $50 \%$ водно-спиртовой $\left(30^{\circ}\right)$ раствор фрруктозы. С целью контроля значений концентрации растворов с помощью рефрактометра Аббе ИРФ-454Б2М (Россия) измерялся показатель преломления применяемых растворов на длине волны 589 нм. Полученные значения представлены в табл. 1.

Исследования проводились в три этапа. На первом этапе определялся фототип кожи каждого из добровольцев, затем анализировалось возможное влияние фракторов окружающей среды на увлажнение, температуру и ИЭ. Для этого выполняли 6 последовательных измерений каждого исследуемого параметра в течение 10 мин. На третьем этапе проводилось собственно тестирование агента. Оно выполнялось с небольшими вариациями протокола. При тестировании глюкозы измерения проводились по следующему протоколу. Сначала измеряли биофизические параметры кожи до нанесения агента (первое измерение). При тестировании 50\% водно-спиртового раствора фрруктозы сначала также измеряли биофизические параметры до нанесения агента (первое измерение). Агент наносился на поверхность исследуемого участка кожи на 1 мин, после чего он удалялся при помощи фрильтровальной салфетки. После удаления агента снова проводились измерения биофизиче- ских параметров, которые занимали примерно 1 мин. Затем агент снова наносился на исследуемый участок, и следующее измерение осуществлялось через 1 мин, и так до 10 мин чистого времени аппликации агента или полного времени аппликации и измерения примерно 20 мин (всего 11 серий) (см. рис. 4). После 20-й минуты агент наносили на 8-9 мин. В конце этого периода салфеткой убирали остатки агента и проводили измерения параметров (12-я серия). Далее проводили только измерения биофизических параметров кожи без дальнейшего нанесения оптических просветляющих агентов, вплоть до 60-й минуты (1315-я серия) (см. рис. 4).

Материалы исследования обработаны с помощью статистических методов с использованием пакета прикладных программ STATISTICA (v 10.0).

\section{Результаты}

Биофизические параметры кожи изучены у 18 добровольцев на левом и правом предплечье (36 объектов). В качестве примера в табл. 2 представлены временны'е зависимости увлажнения, температуры и ИЭ кожи без воздействия дегидратирующего агента для двух добровольцев. Представленные табличные значения свидетельствуют о достаточно стабильном уровне биофизических параметров кожи при неизменных условиях окружающей среды и положении испытуемого. Незначительный разброс параметров в основном связан с индивидуальными особенностями добровольцев и для одного и того же добровольца в спокойном состоянии без внешних воздействий не превышает нескольких процентов.

На рис. 1-3 показаны временные зависимости для показателей увлажнения, температуры и ИЭ поверхности кожи при воздействии растворов (30, 40 и 50\%) глюкозы $(n=36)$.

Результаты, полученные при 20-минутном воздействии 30\% водного раствора глюкозы на кожу, позволяют заключить, что за первые 20 мин наблюдения происходит спад увлажнения кожи, что хорошо коррелирует с поведением (снижением) ИЭ кожи и температуры на исследуемом участке кожи. Однако эти изменения незначительные: для увлажнения они на уровне $12 \%$ от начального значения до аппликации агента, для ИЭ снижение составляет 7\%, а для температуры

\begin{tabular}{lc}
\hline Дегидратирующий агент & Показатель преломления \\
\hline $30 \%$ раствор глюкозы в воде & 1,379 \\
\hline $40 \%$ раствор глюкозы в воде & 1,391 \\
\hline $50 \%$ раствор глюкозы в воде & 1,398 \\
\hline $50 \%$ водно-спиртовой раствор фруктозы & 1,415 \\
\hline
\end{tabular}


Таблица 2 Значения биосризических параметров кожи $(M \pm m)$ двух добровольцев (А. и Б.), измеренные в 10-минутном интервале

\begin{tabular}{lcc}
\hline & Доброволец А. & Доброволец Б. \\
\hline Левая рука & & $16,1 \pm 0,1$ \\
\hline Увлажнение, H & $22,0 \pm 0,1$ & $92,2 \pm 0,1$ \\
\hline Эритема, Е & $110,2 \pm 0,0$ & $35,1 \pm 0,0$ \\
\hline Температура, T & $32,3 \pm 0,0$ & $16,3 \pm 0,1$ \\
\hline Правая рука & & $98,0 \pm 0,0$ \\
\hline Увлажнение, H & $23,0 \pm 0,1$ & $35,0 \pm 0,0$ \\
\hline Эритема, Е & $113,0 \pm 0,0$ & \\
\hline Температура, T & $32,6 \pm 0,0$ & \\
\hline
\end{tabular}

a

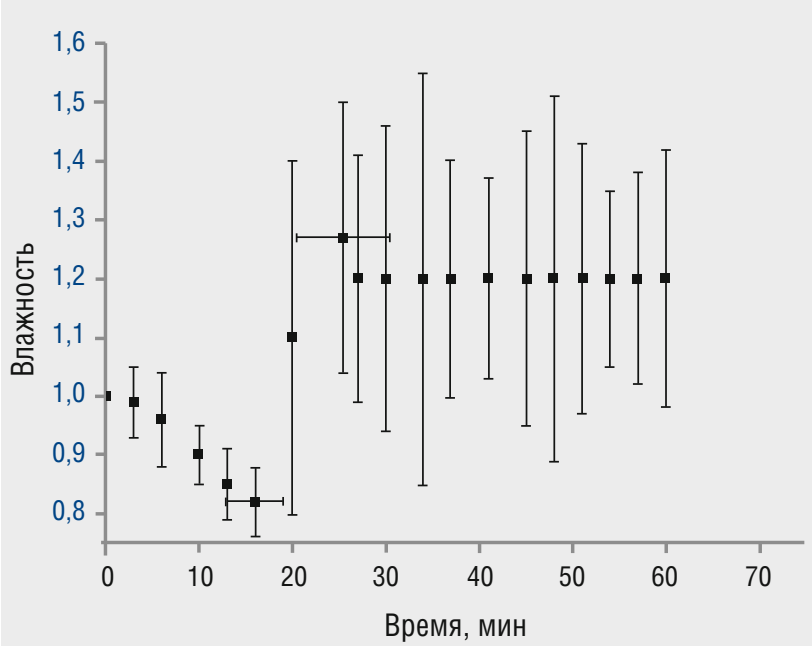

$\sigma$

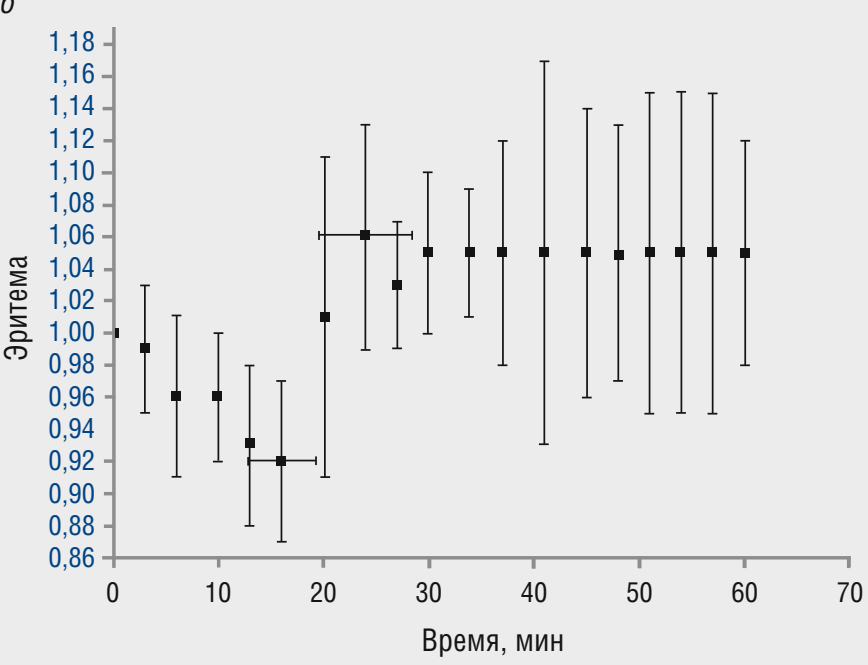

B

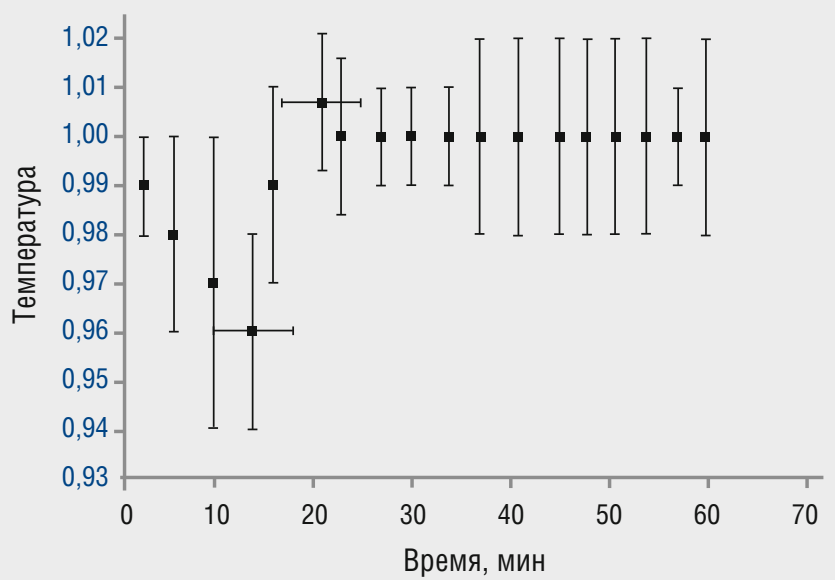

Рис. 1. Временны́е зависимости биосизических параметров кожи при полном 20-минутном воздействии $30 \%$ водного раствора глюкозы, нормированные и усредненные по всем добровольцам $(n=36)$.

Здесь и на рис. 2-4: полное время наблюдения 60 мин; а — влажность; б — эритема; в - температура 
a

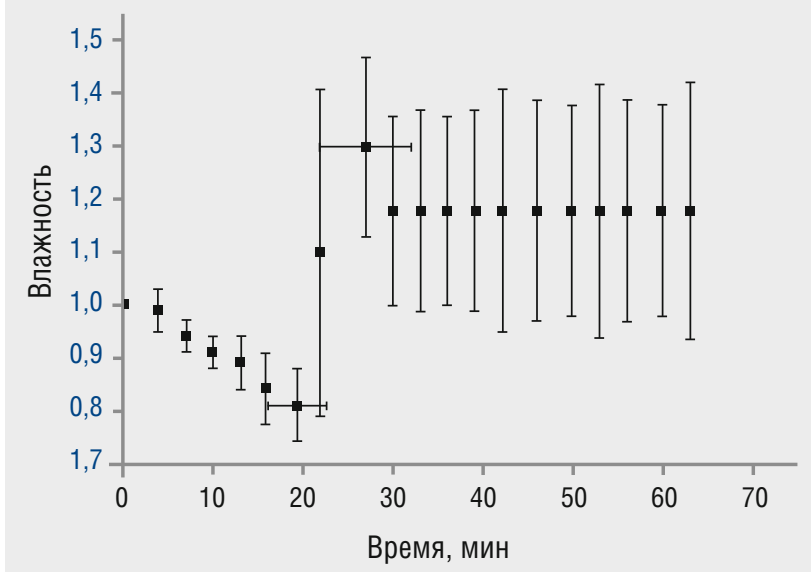

$\sigma$

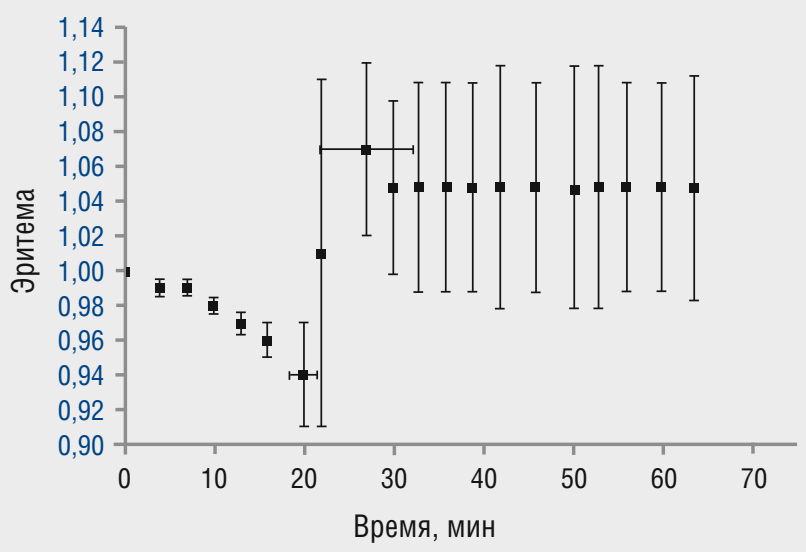

B

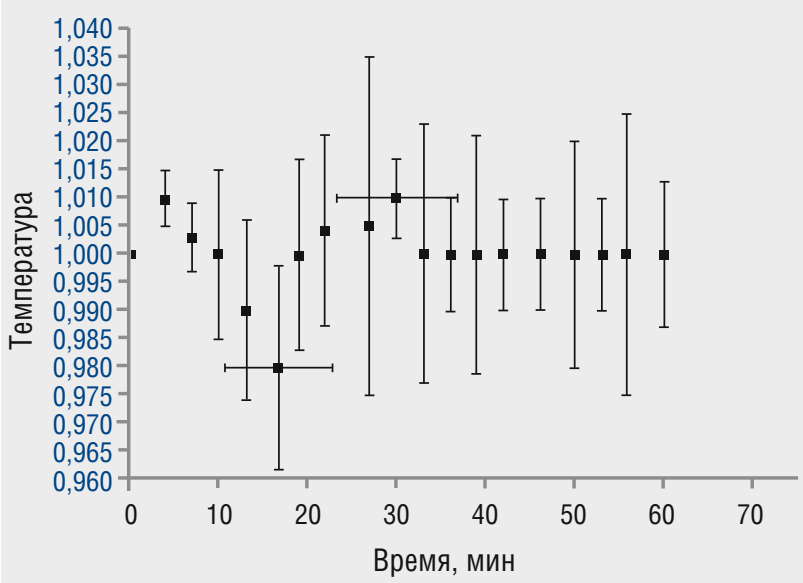

Рис. 2. Временнь́е зависимости биофизических параметров кожи при 20-минутном воздействии 40\% водного раствора глюкозы, нормированные и усредненные по всем добровольцам $(n=36)$ a

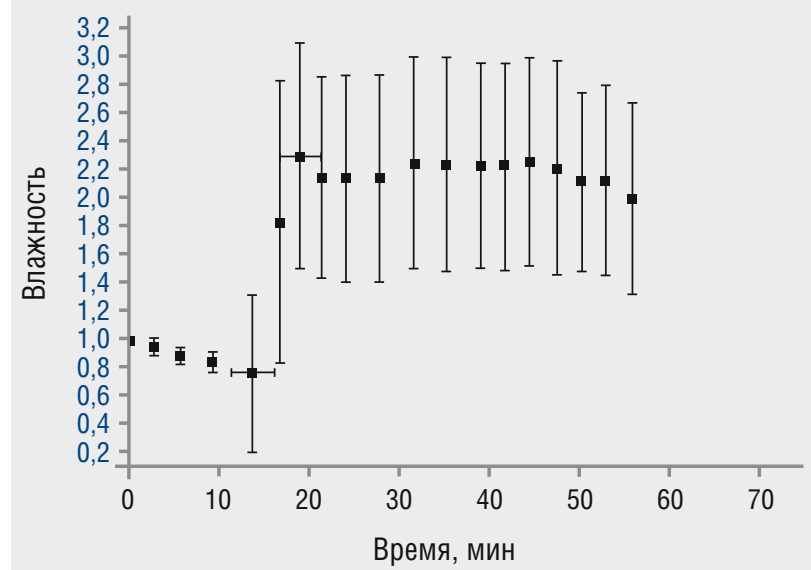

$\sigma$

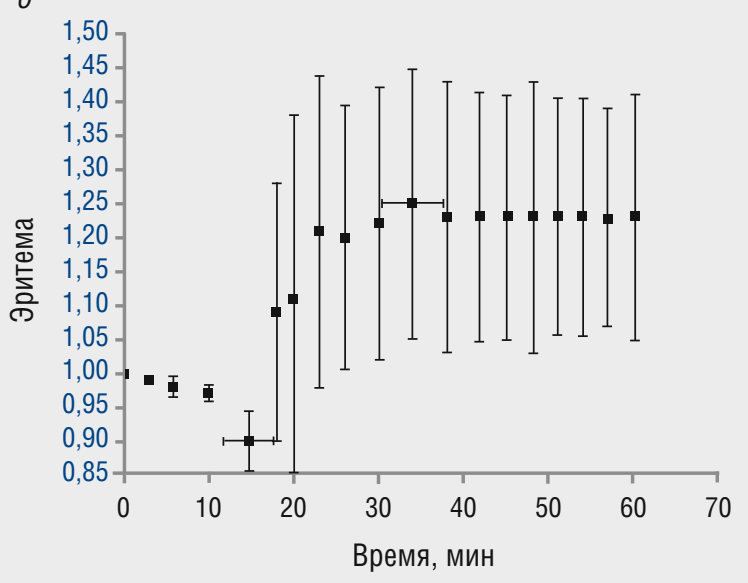

B

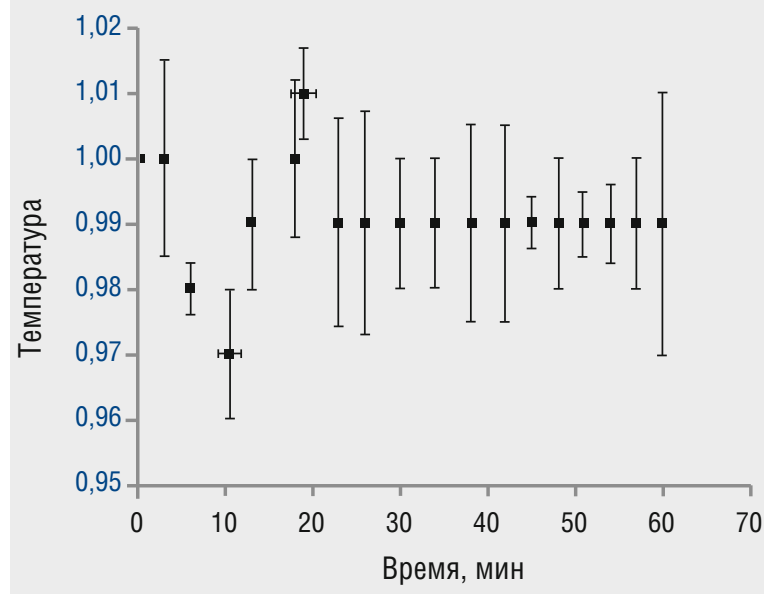

Рис. 3. Временны'е зависимости биофизических параметров кожи при 20-минутном воздействии 50\% водного раствора глюкозы, нормированные и усредненные по всем добровольцам $(n=36)$ 
поверхности кожи только 5\% от начального значения. Такое снижение значений параметров происходит на временно́м интервале 10-20 мин. Далее в течение 40 мин уже без приложения агента наблюдается значительный рост всех трех параметров как физиологический отклик на воздействие глюкозы. Увлажнение увеличивается на 50\% по сравнению с минимальным значением, эритема на 28\%, а температура на $8,7 \%$, фактически температура возвращается к исходному состоянию. Близкие изменения наблюдаются и для более концентрированных водных растворов глюкозы с некоторым увеличением степени дегидратации и ИЭ с ростом концентрации. Для 50\% глюкозы потеря влажности составляет уже 24\%, а снижение ИЭ $10 \%$ на интервале 17 мин.

На рис. 4 показаны временны'е зависимости для увлажнения, ИЭ и температуры поверхности кожи при воздействии 50\% водно-спиртового раствора фруктозы, усредненные по всем добровольцам.

Отчетливо видно, что минимальная степень дегидратации кожи наблюдается на 10-й минуте, когда происходит резкий спад увлажнения у всех добровольцов примерно на 75\% по сравнению с начальным значением, который через следующие 2 мин сменяется таким же резким подъемом увлажнения примерно на $86 \%$ по сравнению с начальным значением, что может свидетельствовать о выходе свободной воды из нижних слоев кожи в верхние.

Воздействие 50\% раствора фруктозы в смеси воды со спиртом вызывает эфрфективное уменьшение увлажнения кожи. Это объясняется характерными для спирта свойствами растворять липидные мостики между корнеоцитами рогового слоя, тем самым создавая в нем аквапоры для более свободной диффузии воды из кожи и гиперосмотического (дегидратирующего) агента внутрь кожи [21]. Кроме того, ИЭ и температура кожи также имеют минимум, совпадающий во времени с минимумом увлажнения. ИЭ уменьшается довольно заметно (на 11\%), а температура снижается, хотя и незначительно, но имеет четко выраженный минимум на 10-й минуте.

Для определения наиболее эффективного дегидратирующего агента проведен анализ изменения биофизических параметров в первую фразу воздействия, когда происходит уменьшение увлажнения. Для этого вводились следующие параметры:

$$
\begin{aligned}
& \Delta_{\text {увл }}=\left(M_{0}-M_{t}\right) \cdot 100 \%, \\
& \Delta_{\text {эрит }}=\left(E_{0}-E_{t}\right) \cdot 100 \%, \\
& \Delta_{\text {темп }}=\left(T_{0}-T_{t}\right) \cdot 100 \%,
\end{aligned}
$$

где $M_{0}, T_{0}$ и $E_{0}$ - увлажнение, ИЭ и температура исследуемого участка кожи до начала воздействия агента соответственно; $M_{t}, T_{t}$ и $E_{t}$ - минимальные значения увлажнения, температуры и ИЭ исследуемого участка кожи после начала воздействия агента. a

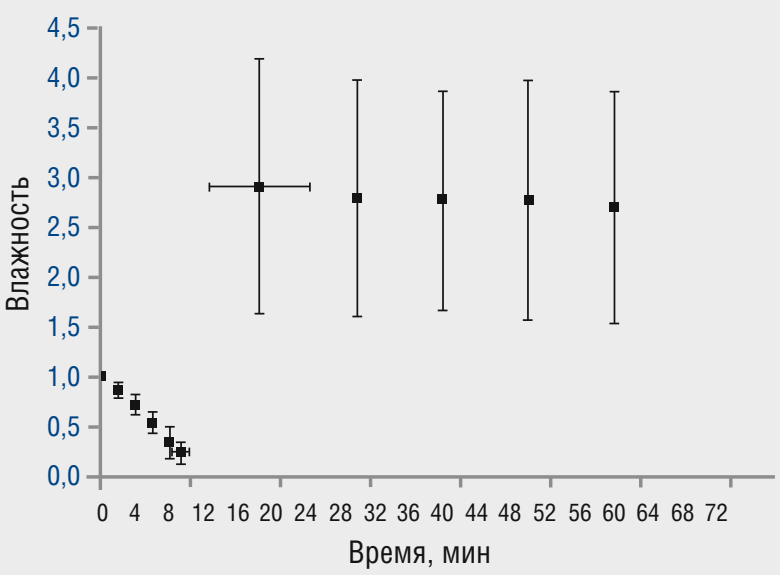

$\sigma$

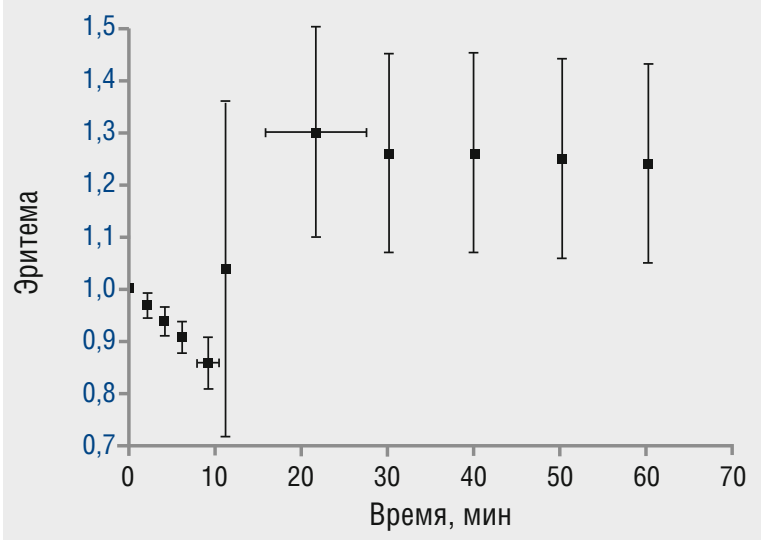

$B$

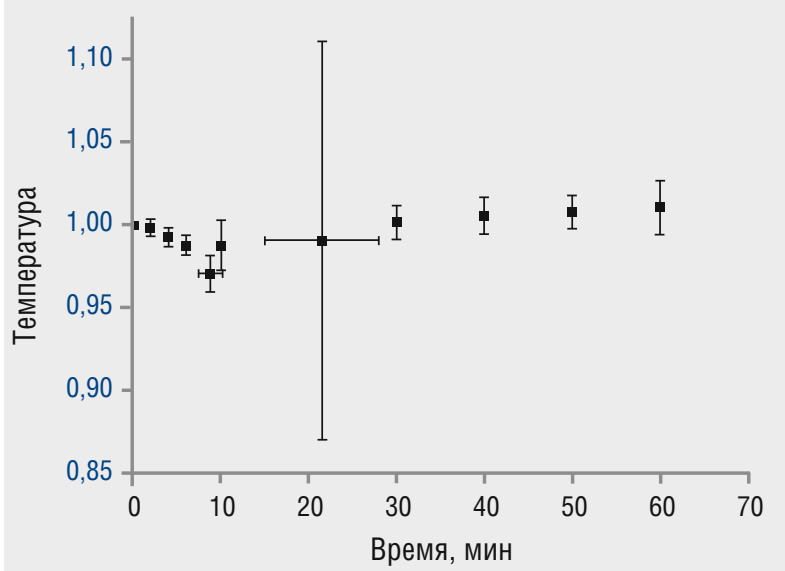

Рис. 4. Временны'е зависимости биосризических параметров кожи при полном 20-минутном воздействии раствора фрруктозы (50\%) в водно-спиртовой смеси $\left(30^{\circ}\right)$, нормированные и усредненные по всем добровольцам $(n=36)$ 
Таблица 3

Относительные изменения биофизических параметров кожи в момент достижения минимального значения увлажнения

\begin{tabular}{lcccc}
\hline Дегидратирующий агент & $\Delta_{\text {увл }}, \%$ & $\Delta_{\text {эрит }}, \%$ & $\Delta_{\text {темп }}, \%$ & Минимум увлажнения, мин \\
\hline 30\% раствор глюкозы в воде & 18 & 8 & 4 & $15-20$ \\
\hline 40\% раствор глюкозы в воде & 19 & 6 & 1 & 19 \\
\hline $50 \%$ раствор глюкозы в воде & 24 & 10 & 3 & 15 \\
\hline $50 \%$ водно-спиртовой раствор фруктозы & 75 & 14 & 3 & $8-10$ \\
\hline
\end{tabular}

Полученные результаты приведены в табл. 3.

Результаты исследования показали, что степень и время дегидратации кожи существенно определяются способом аппликации иммерсионного агента и его составом. В зависимости от применяемой технологии можно получить как уменьшение, так и увеличение степени увлажнения кожи, что связано с физиологическим откликом кожи на окклюзию и осмотическое действие препаратов. Препарат не должен долгое время находиться на поверхности кожи и не должен препятствовать испарению воды с поверхности кожи.

Наиболее эффрективным дегидратирующим агентом из исследованных является 50\% водно-спиртовой раствор фруктозы. После 10 мин применения данного агента происходит резкий спад увлажнения - на 75\% по сравнению с начальным значением, что свидетельствует о выходе свободной воды из нижних слоев кожи в верхние. Возникающий эфффект иммерсионного просветления кожи может быть использован в исследованиях по оптической и терагерцовой диагностике состояния кожи.

\section{Обсуждение}

При нанесении на кожу гиперосмотических агентов распределение вещества происходит в поверхностных слоях эпидермиса. Пропитанные таким образом слои в течение некоторого времени выполняют двоякую роль - роль “окклюзионной пленки» и роль абсорбера воды, которая покидает верхние слои эпидермиса, устремляясь наружу. Это приводит к вре́менному снижению увлажнения. В этот момент регистрируется также некоторое снижение ИЭ, обусловленное уменьшением количества функционирующих микрососудов дермы в условиях «окклюзии». В дальнейшем осмотический агент распределяется в более глубокие слои эпидермиса, теряет концентрацию в результате связывания с внутриэпидермальной водой и перерас- пределения в тканях. Достигнув более глубоко расположенных слоев эпидермиса (зернистого и шиповидного), осмотический агент, по-прежнему сохраняющий сравнительно высокую концентрацию по отношению к электролитному составу межтканевой жидкости, вызывает компенсаторное расширение микрососудов и диффрузию воды из сосудов в дерму и далее в эпидермис, что приводит к увеличению как ИЭ, так и влажности. Эти процессы протекают до того момента, пока в данном участке кожного покрова не будет восстановлено состояние изотонии.

Полученное в клиническом эксперименте характерное время дегидратации в пределах 8-10 мин для всех добровольцев достаточно хорошо соответствует времени дифффузии воды в живом эпидермисе. Например, для коэффициента диффузии воды в эпидермисе $D_{\mathrm{E}} \sim 2 \cdot 10^{-7} \mathrm{~cm}^{2} / \mathrm{c}$ и его толщине $I_{\mathrm{E}}=100 \mathrm{MKM}$ $\tau_{\mathrm{D}}=R^{2} / D \cong 5 \cdot 10^{2}$ c, т. е. $\sim 8,3$ мин $[22,23]$.

\section{Заключение}

Клинически доказана возможность использования измерений влажности, температуры и эритемы кожи для мониторинга временного обезвоживания эпидермиса кожи человека при местном применении иммерсионного гиперосмотического агента. Показано, что агент в виде раствора фрруктозы (50\%) в смеси спирта (30\%) и воды (20\%) обеспечивает эфрфективное обезвоживание эпидермиса в течение 8-10 мин. Именно в течение этого периода следует ожидать более глубокого проникновения оптического излучения в кожу человека за счет снижения рассеяния (более плотная упаковка ткани), а также среднего ИК- и терагерцового излучения за счет снижения поглощения, связанного с вре́менной потерей воды. В результате чего можно ожидать улучшения качества получаемых изображений различных патологических изменений в коже, включая онкологические новообразования. І 


\section{Литература}

1. Rezaykin A.V., Kubanova A.A., Rezaykina A.V. Non-invasive methods of the human skin investigation. Vestnik dermatologii i venerologii 2009; (6): 28—32. [Резайкин А.В., Кубанова А.А., Резайкина А.В. Неинвазивные методы исследования кожи. Вестн дерматол и венерол 2009; (6): 28-32.]

2. Shtirshnayder Yu.Yu., Michenko A.V., Katunina O.R., Zubarev A.R. New non-invasive imaging technology in dermatology. Vestnik dermatologii i venerologii 2011; (5): 41—53. [Штиршнайдер Ю.Ю., Миченко А.В., Катунина О.Р., Зубарев А.Р. Современные неинвазивные технологии визуализации в дерматологии. Вестник дерматологии и венерологии 2011; (5): 41 — 53.]

3. Sinichkin Yu.P., Utz S.R. In vivo reflectance and fluorescence spectroscopy of the human skin. Saratov: Izd-vo SGU; 2001. [Синичкин Ю.П., Утц С.P. In vivo отражательная и фрлуоресцентная спектроскопия кожи человека. Саратов: Изд-Во СГУ; 2001.]

4. Sinichkin Yu.P., Kollias N., Utz S.R. et al. Reflectance and fluorescence spectroscopy of the human skin in vivo. V: Opticheskaya biomeditsinskaya diagnostika: v 2 t. Pod red. V.V. Tuchina. Moskva: Fizmatlit 2007; 1: 77-124. [Синичкин Ю.П., Коллиас Н., Утц С.Р. с соавт. Отражательная и фрлуоресцентная спектроскопия кожи человека in vivo. B: Оптическая биомедицинская диагностика: в 2 т. Под ред. В.В. Тучина. М: Физматлит 2007; (1): 77-124.]

5. Utz S.R. Optics of the human skin. V: Nizkointensivnaya lazernaya terapiya. Pod red. Moskvina S.V., Buylina V.A. M: T00 «Firma «Tehnika», 2000. 58-70. [Утц С.Р. Оптика кожи В: Низкоинтенсивная лазерная терапия. Под ред. Москвина С.В., Буйлина В.А. М: ТОО «Фирма «Техника» 2000; 58-70.]
6. Gratton E. Deeper tissue imaging with total detection. Science 2011; 331: 1016-1017.

7. Liew Y., McLaughlin R., Wood F., Sampson D. Reduction of image artifacts in three-dimensional optical coherence tomography of skin in vivo. Journal of Biomedical Optics 2011; 16 (11): 116018.

8. Tuchin V.V. A clear vision for laser diagnostics (review). IEEE Journal Quantum Electronics 2007; 13: 1621-1628.

9. Tuchin V.V. Optical Clearing of Tissues and Blood., Bellingham: SPIE Press: 2006.

10. Agrba P., Kirillin M., Abelevich A. et al. Compression as a method for increasing the informativity of optical coherence tomography of biotissue. Optics and Spectroscopy 2009; 107 (6): 853-858.

11. Guzelsu N., Federici J., Lim H. et al. Measurement of skin strech via light reflection. Journal of Biomedical Optics 2003; 8: 80—86.

12. Yu T., Wen X., Tuchin V. et al. Quantitative analysis of dehydration in porcine skin for assessing mechanism of optical clearing. Journal of Biomedical Optics 2011; 16: 095002.

13. Lin W.-C., Motamedi M., Welch A. Dynamics of tissue optics during laser heating of turbid media. Applied Optics 1996; 35 (19): 3413-3420.

14. Genina E.A., Bashkatov A.N., Sinichkin Yu.P. et al. Optical ckearing of biological tissues: prospects of application in medical diagnostics and phototherapy. Journal of Biomedical Photonics and Engineering 2015; 1 (1): 22—58.
15. Doubrovskii V.A., Yanina I.Yu., Tuchin V.V. Kinetics of changes in the coefficient of transmission of the adipose tissue in vitro as a result of photodynamic action. Biophysics 2012; 57 (1): 94—98.

16. Yanina I.Yu., Trunina N.A., Tuchin V.V. Optical coherence tomography of adipose tissue at photodynamic/photothermal treatment in vitro. Journal Innovation Optical Health Science 2013; 6(2): 1350010.

17. Zhu D., Larin K.V., Luo Q., Tuchin V.V. Recent progress in tissue optical clearing. Laser Photonics Review 2013; 7 (5): 732-757.

18. Handbook of non-invasive methods and the skin / ed. By J.Serup et al. — 2nd ed., CRC; 2006.

19. Tagami H. Electrical measurement of the hydration state of the skin surface in vivo // British Journal of Dermatology 2014; 171: 29—33.

20. Dolotov L.E., Sinichkin Yu.P., Utz S.R. et al. Design and evaluation of a novel portable erythema-melanin-meter. Lasers in Surgery and Medicine 2004; 34 (2): 127-135.

21. Loden M. Interaction between the stratum corneum and topically applied products: regulatory, instrumental and formulations issues with focus on moisturizers. British Journal of Dermatology 2014; 171: 38-44.

22. Sato J., Yanai M., Hirao N., Denda M. Water content and thickness of the stratum corneum contribute to skin surface morphology. Arch. Dermatology Research 2000; 292: 412-417.

23. Verdier-Sevrain S., Bonte F. Skin hydration: a review on its molecular mechanisms. Journal Cosmet. Dermatology 2007; 6: 75—82.

об авторах:

С.Р. Утц - Д.м.н., профессор, зав. кафедрой кожных и венерических болезней ГБОУ ВПО «Саратовский государственный медицинский университет им. В.И. Разумовского»

В.В. Тучин - д.ф-м.н., профессор, зав. кафедрой оптики и и биофотоники Саратовского государственного исследовательского университета им. Н.Г. Чернышевского

Е.М. Галкина - ассистент кафредры кожных и венерических болезней ГБОУ ВПО «Саратовский государственный медицинский университет им. В.И. Разумовского»

\section{Конфликт интересов}

Авторы заявляют об отсутствии потенциального конфрликта интересов, требующего раскрытия в данной статье 